\title{
THE SECOND SALPAUSSELKÄ AT KARKKILA, SOUTHERN FINLAND
}

\author{
GunNar GlüCkert
}

Glǘckert, Gunnar 1975: The Second Salpausselkä at Karkkila, southern Finland. Bull. Geol. Soc. Finland 47, 45-53.

\begin{abstract}
This paper describes the results of glacial geological field investigations carried out in 1974 in the $10 \mathrm{~km}$ wide zone of the Second Salpausselkä in the area between Karkkila and Loppi in southern Finland. The 2nd Salpausselkä runs in three main parallel belts, each of them forming one or several broken rows of moraine ridges, glaciofluvial deltas of various types, and other transverse formations and deposits. The "transverse eskers» described in some previous papers are interpreted by the present author in the main as gradual forms of glaciofluvial marginal deltas, deposited in general in the sea in front of the ice margin. The typical and flat-topped forms of delta in general grew up to the water level of the ancient Baltic Ice Lake, situated in the study area at 140$150 \mathrm{~m}$ above sea level. The sharp-crested primary form of delta did not grow up to water level. The meltwater streams also produced, in addition to separate deltas, radial eskers, often rich in deltas, too. The activity of the ice is shown by the halts or short advances. The 2nd Salpausselkä system was formed in three main stages and the formation lasted about 200 years, $8500-8300$ B.C.

Gunnar Gluickert, Institute of Quaternary Geology, University of Turku, SF-20500 Turku 50, Finland.
\end{abstract}

\section{Introduction}

The purpose of this paper is to explain the results of the author's study dealing with the end moraine system of the Second Salpausselkä in the areas of Karkkila and Loppi in southern Finland (Fig. 1 and 2). Leiviskä (1920), Virkkala (1963) and Aartolahti (1968) have published papers including maps dealing with the Salpausselkä formations in southern Finland, covering the 2nd Salpausselkä in the area of Karkkila on quite a large scale. In 1967 Virkkala compiled the mapping results of the superficial deposits in the area of Karkkila. The explanation for this map of Quaternary deposits, Sheet 2042, Karkkila, has not yet been published. By studying anew the broad 2nd Salpausselkä ice marginal belt in the same area in 1974 and interpreting all transverse formations and radial eskers on the basis of his own field observations, the present author aimed to complete the earlier picture of the 2nd Salpausselkä. In particular he divided the ice marginal ridges, composed in the main of glaciofluvial drift, into three gradual forms of delta. Most of these ridges were earlier interpreted by Virkkala (1963) and 


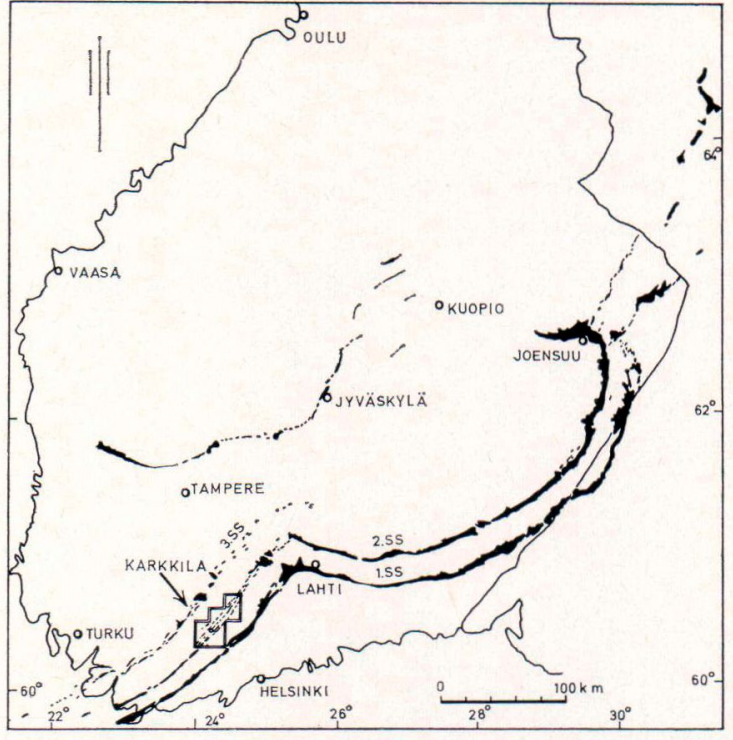

Fig. 1. Study area.

Aartolahti (1968) in the main as stransverse eskers", deposited in fractures and crevasses in the ice running parallel to the ice margin. The present author did not find any formations which genetically could be explained as transverse eskers, but, instead, gradual forms of glaciofluvial delta, in general deposited in the sea in front of the ice margin. Some of these ridges grew up to the water level of the ancient Baltic to form well developed delta plains at 140-150 $\mathrm{m}$ above sea level.

Several new transverse formations and accumulations were found within the 2nd Salpausselkä, not mentioned in previously published geological literature or maps. The retreat of the melting ice margin (deglaciation) in the area was followed on the basis of the trend of the ice marginal formations and radial esker courses. The aim in the map in Fig. 2 is to present the results in more detail than has been done on the maps published earlier.

In the study area the system of the 2 nd Salpausselkä, c. $10 \mathrm{~km}$ wide and trending from $\mathrm{SW}$ to NE, is composed of three main parallel belts, 2.SSa, 2.SSb and 2.SSc, forming different ice marginal formations of glacial drift (Fig. 2). The following principal elements were distinguished by the author:

- large and small moraine ridges,

- three gradual forms of glaciofluvial delta, and

- other transverse accumulations.

\section{Moraine ridges}

Along with glaciofluvial deltas, numerous moraine ridges of various size, running parallel to the ice margin, were found in the belts of the 2nd Salpausselkä. The size of the large ridges varies from 100 to $2000 \mathrm{~m}$ in length, $20-100 \mathrm{~m}$ in width $3-20 \mathrm{~m}$ in height. In general the ridges are asymmetrical, the distal slant being a little steeper than the proximal slope. The inclination of the slopes of the large moraine ridges varies between 15 and $35^{\circ}$. Their crest is narrow and often rich in blocks and big boulders. The sections in these ridges show that they are composed of poorly sorted glacial drift and sandy till. Sometimes the big ridges are also composed of quite well washed glaciofluvial drift, stratified sand and gravel with stones and blocks. In some localities till has been deposited in the proximal and glaciofluvial drift in the distal part of the accumulation, belonging to the type of complex end moraine by Aartolahti (1968 p. 59).

The large moraine ridges occur individually in the belts of the 2nd Salpausselkä, whereas the smaller ridges often occur in clusters, forming in general a group of 3 to 10 ridges (Fig. 2). Prominent large moraine ridges are for example the formations S of Lake Kesijärvi, E of Lake Ojajärvi (Loppi), S of Lake Loppijärvi (Järventausta), and $\mathrm{N}$ of Karkkila (Fig. 2).

The small moraine ridges are shorter and lower than the large ridges. The small ridges are $1-5$ $\mathrm{m}$ high, 20-30 $\mathrm{m}$ wide and $50-500 \mathrm{~m}$ long, composed entirely of till rich in blocks on the 
THE SECOND SALPAUSSELKÄ AT KARKKILA, SOUTHERN FINLAND
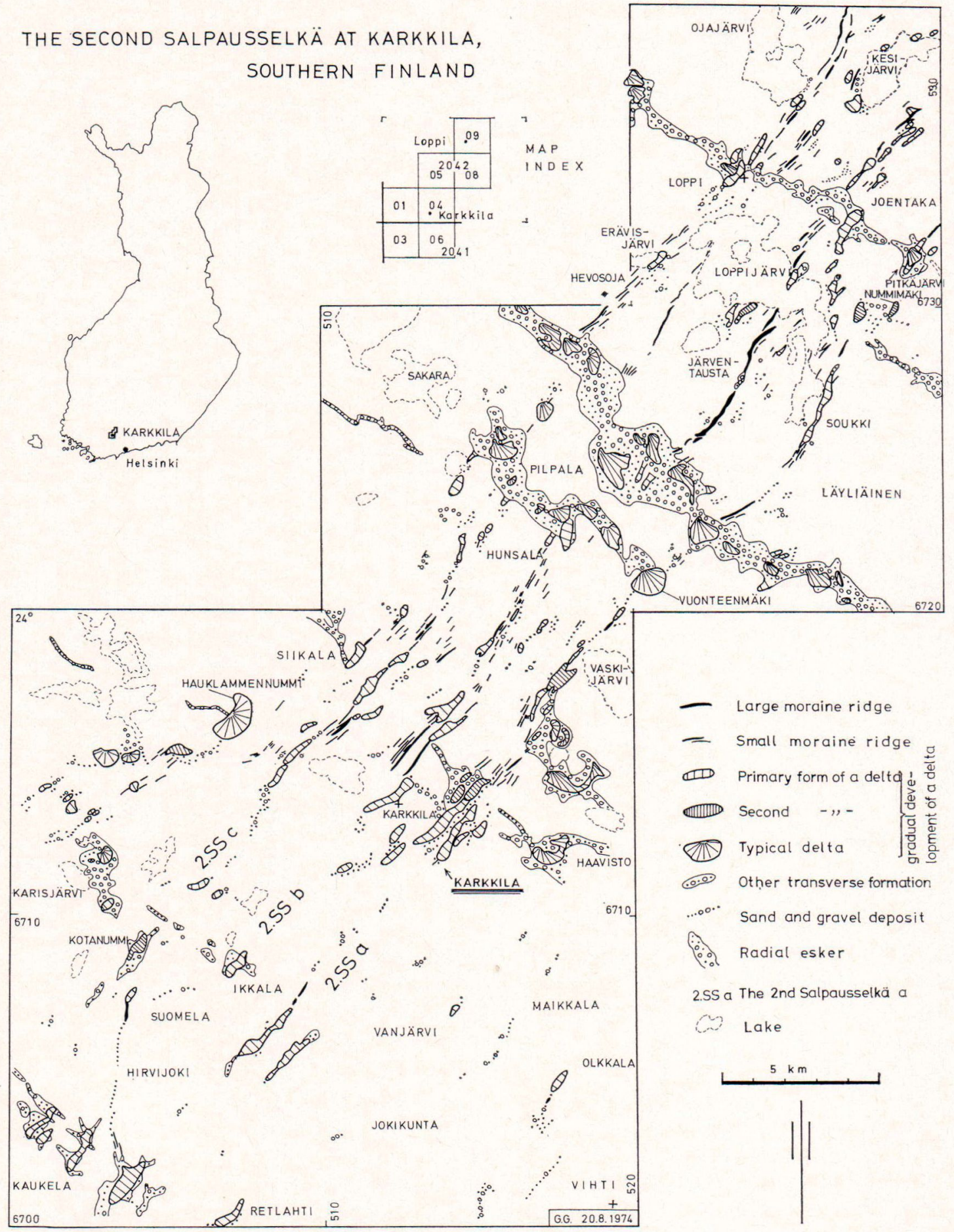

Fig. 2. The Second Salpausselkä at Karkkila, southern Finland. 
surface. Most of the moraine ridges in the area belong to the small ridges (Fig. 2).

The moraine ridges have been built by the action of a slightly active ice margin. By deposition the blocky till flowed down from the ice to form narrow moraine ridges along the ice margin. The main part of the ridges were formed in front of the ice margin; some ridges, however, have been deposited in transverse crevasses of the ice margin.

By depositing the moraine ridges there were no meltwater streams rich in glaciofluvial material, as there were in cases of deposition of the radial eskers and the various forms of delta.

In cases of deposition of large ridges, the ice margin halted for about 20-30 years, as been presented also by Virkkala (1963 p. 45). The small ridges were formed when the ice margin gradually retreated and deposited at each short halt (about $1-3$ years) one row of short ridges. No strong advance of the ice, depositing typical push end moraines, e.g. as found in northern West Germany (Gripp 1964, Glückert 1973), were observed in the study area. However, in some gravel pits in the vicinity of Karkkila clear signs of push structure were observed in the proximal parts of moraine ridges.

\section{Glaciofluvial deltas}

Within the three belts of the Second Salpausselkä the author has distinguished three gradual forms of glaciofluvial delta accumulations deposited in supraglacial conditions at the ice margin (Fig. 3). These gradual forms of delta are the following:

- primary form of delta (Fig. $3 \mathrm{a}$ ),

- second form of delta (Fig. 3 b), and

- fully developed delta plain (Fig. 3 c) (Fig. 2).

The primary and second forms of delta represent 200-3000 $\mathrm{m}$ long, 5-60 $\mathrm{m}$ high, narrow, concave ridges with sharp crests, composed of glaciofluvial gravel and sand, sometimes rich in stones and blocks. The structure

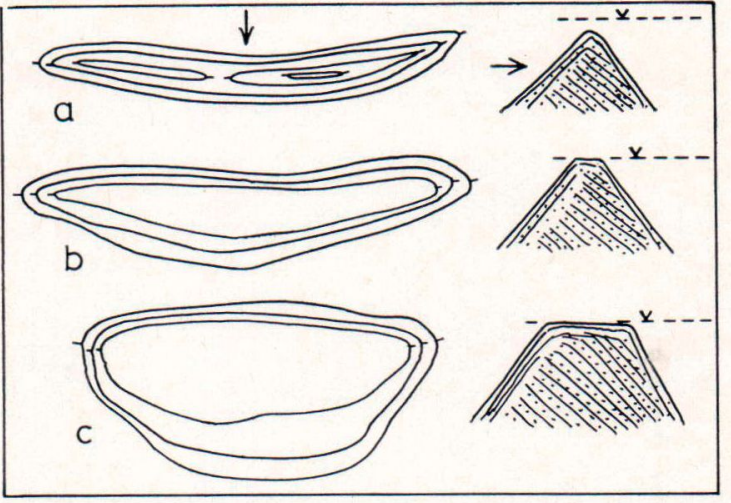

Fig. 3. Gradual forms of glaciofluvial delta:

a. primary form: sharp-crested ridge, the crest not reaching the water level of the Baltic (Baltic Ice Lake).

b. second form: narrow flat-topped crest, which has grown up to the water level.

c. fully developed delta: broad plain, which has grown up to the water level.

The arrows show the proximal slope and the direction of deposition of a delta. The distance between two contour lines is 5 metres.

of the delta ridges can be observed in several sections and gravel pits. The stratified drift of the ridges is well washed, and the bedding tilts in general in the distal direction (SE), mostly showing a typical delta structure. In some ridges, however, the bedding seems to tilt in the direction of the slopes (Fig. 4) (see also Virkkala 1963 p. 42 and Aartolahti 1968 p. 48).

The primary forms of delta did not grow up to the water level of the ancient Baltic Ice Lake, but rested some metres beneath the water surface. There was not enough material to build up a delta plain at water level, or the ice margin did not halt long enough in the same place. The sharp crests of the delta ridges lie at almost $120-135 \mathrm{~m}$ above sea level, the level of the Baltic Ice Lake being $140-150 \mathrm{~m}$ above sea level. Examples of such narrow primary forms of delta are the $30-60 \mathrm{~m}$ high ridges at Karkkila, the ridge of Erävisharju, and the ridges at Soukki (Loppi) (Fig. 2 and 3 a).

The second form of glaciofluvial delta is a ridge with flat-topped crest, broader than the primary 
form of delta ridge (Fig. $3 \mathrm{~b}$ ). The ridge with narrow but even crest was deposited at the ancient water level of the Baltic. In most cases there was enough material and time to build up this type of delta virtually up to the water level. The ice was halted for a longer time by depositing such a high delta ridge. The even crests of the most of these deltas have later been deformed by shore action of the ancient tilted Baltic. Examples of the flat-topped second form of an delta are the formations of Kotanummi between Ikkala and Karisjärvi and of Nummimäki east of Lake Loppijärvi (Fig. 2).

The typical deltas form even plains of various size within the belts of the 2nd Salpausselkä, NW of the Salpausselkä system, and within the radial eskers, running across the 2nd Salpausselkä from SE to NW (Sauramo 1958). These delta plains have grown up at the water level of the ancient Baltic, and their crests lie at 140 $150 \mathrm{~m}$ above sea level (Fig. 2 and $3 \mathrm{c}$ ). A typical delta structure is to be seen in most of the many gravel pits and sections. Strong meltwater steams deposited large delta formations over about $10-50$ years when the ice margin rested in the same place. Examples of typical deltas are, e.g. Vuonteenmäki at Vaskijärvi and Hauklammennummi west of Karkkila (Fig. 2). The delta $\mathrm{N}$ of Pilpala seems to be covered with morainic material. On the delta of Pitkäjärvi there run a ring-formed $2-5 \mathrm{~m}$ high shore bar, composing of stones, lying at $150 \mathrm{~m}$ above sea level, and belonging to the Baltic Ice Lake (Fig. 2).

The deltas, especially the narrow delta ridges (Fig. $3 \mathrm{a}$ and b) occur in general at the SE side of deep basins of the underground, e.g. on the eastern shores of lakes or on the SE side of other depressions (bogs). In these deep Ushaped terminal basins separate tongues of ice rested for quite a long time during deglaciation. Then supraglacial meltwater streams had time to deposit sorted drift in abundance at the front of the ice ending in the sea, and formed slight concave ridges at the end of the terminal basins: e.g. the high delta ridges at Soukki, which lie at the end of the U-shaped bays of Lake Loppijärvi (Fig. 2). The steep distal slope of the delta ridges does not necessarily prove contact with dead ice lying just in front of the ice margin. Steep slopes also were formed when the drift was deposited from the ice directily in the sea.

On both sides of the delta ridges, within the belts of the 2nd Salpausselkä, there often occur a cluster of small moraine ridges, indicating a gradual retreat of the ice margin. These parallel small moraine ridges thus together correspond to the neighbouring delta ridges of stratified drift, occuring especially at the end of bays of lakes. Instead of a delta ridge, a cluster of moraine ridges were formed, e.g. SW of Soukki, and $\mathrm{NE}$ and $\mathrm{N}$ of Karkkila. In these areas the large delta ridge no longer continues as a delta, but splits into several parallel small moraine ridges (Fig. 2 and 5).

Also Virkkala (1963, Fig. 23, p. 43) has published a map where on the northern side of a U-shaped transverse ridge (esker) at the end of a lake bay (Lake Lastujärvi near Turenki), a cluster of end moraines trend to the NE. These ridges were also formed at the same time as the neighbouring big "transverse esker», at the end of the bay, but the ice margin retreated gradually and deposited at each short halt one row of little moraine ridges.

The present author does not explain the delta ridges as »transverse eskers», although this term sometimes could morphologically be used.

Genetically an esker scarcely was deposited subglacially in a transverse tunnel or crevasse in the ice. However, some ridges in the area may have deposited as small deltas in broad crevasses between the glacier and stagnant blocks of dead ice. The transverse »esker-like» ridges in the study area are not eskers but ice marginal formations belonging to various forms of delta.

Also the large ridges forming the First Sal- 


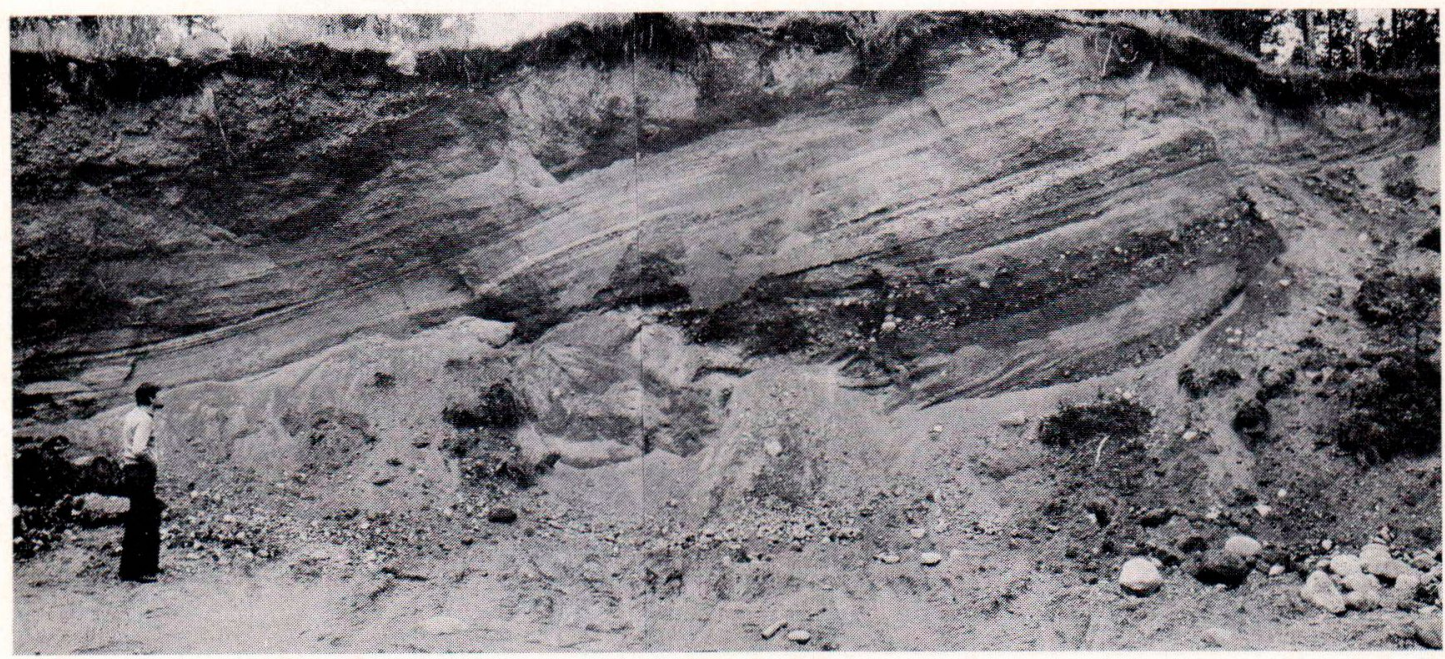

Fig. 4. Delta structure in a delta ridge belonging to the primary form of delta. Gravel pit at Sajaniemi, Loppi. Photo Glückert 14. 8. 1974.

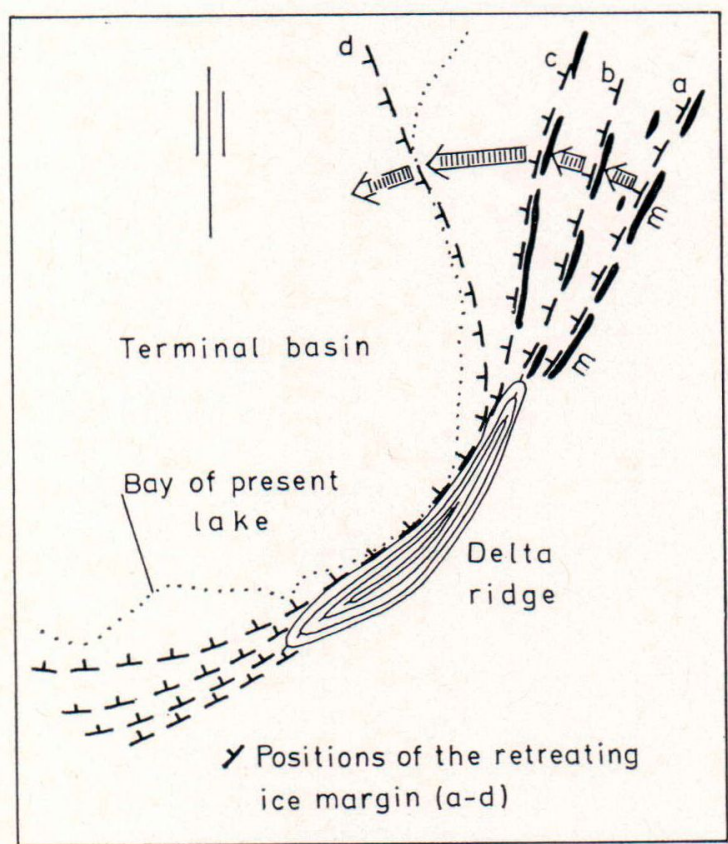

Fig. 5. Schematical positions of a retreating ice tongue in a deep terminal basin of the area, which during one longer halt deposited a delta ridge in the sea at the end of the basin. At the same time as the delta was formed, parallel moraine ridges $(\mathrm{m})$ were deposited during several shorter halts $(a-d)$ of the receding ice margin (arrows) on the northern side of the delta. pausselkä in South Finland compose in the main of washed and sorted drift, the bedding tilting in the distal direction. The formations mostly indicate a delta structure, and were scarcely formed in subglacial conditions in a transverse tunnel or crevasse of the ice, but in general as deltas in the sea in front of the ice margin, as has also been pointed out by Sauramo (1958).

The term stransverse esker» has been used in geological literature, but it's morphogenesis have not been definitively explained. Leiviskä (1920) interprets some ridges within the Salpausselkä formations as »transverse eskers». Tanner (1938 pp. 513-514) use the same term for esker-like formations deposited in transverse marginal cracks or depressions of the ice. According to Mölder $(1960,1966)$ the 2nd Salpausselkä runs west of Lake Saimaa in southern Finland as short eskers. Virkkala (1963) and Aartolahti (1968) explain the narrow, sharp-crested ridges of the 2nd Salpausselkä at Karkkila in the main as "transverse eskers».

V. Okko (1957) has studied the belt of the 2nd Salpausselkä east of Hämeenlinna in South Finland. He also distinguishes a transverse 
esker type, and explains it as genetically analogous with glaciofluvial deltas, as a form of delta that had not time to grow into a full delta (V. Okko 1957 p. 16 and 25). This explanation for the genesis of an unfully developed delta coincides with the opinion of the present author in the Karkkila area (see also Aartolahti 1968 p. 48).

Embleton and King (1969 pp. 387-389) describe the so-called delta-moraines, formed where stationary ice fronts remain for some time, ending in lake or the sea. The deltamoraines were formed adjecent to the stagnant ice, and the deltaic deposits were carried by the meltwater streams into the sea. The typical deltaic structure is overlaid by coarse unstratified morainic material. The delta ridges in the Karkkila area, sometimes with a layer of morainic material in the proximal part, resemble these delta-moraines of Embleton and King (1969).

Price (1973 pp. 157-160) describes rather similar formations deposited by supraglacial meltwater streams in a marginal crevasse that contains an extension of a proglacial lake. After deglaciation these formations form elongated deltas.

Persson (1974 pp. 416-418) has classified the glaciofluvial deposits in southern Sweden. According to him transverse esker is a term covering a number of short esker ridges transverse to the radial eskers. They trend to be transverse on both sides of the main esker and were formed in crevasses around remaining dead-ice blocks.

Several deltas within the Salpausselkä belts grew up to the water level of the Baltic during the Baltic Ice Lake period (Sauramo 1958), $8800-8200$ B.C., occuring as wide and flattopped plains at $140-150 \mathrm{~m}$ above sea level in the area of Karkkila. The line indicating the $28 \mathrm{~m}$ tilt of the Baltic Ice Lake to the level of the Yoldia Sea runs just northwest of the 2nd Salpausselkä (Fig. 6). The tilt is marked in the terrain as two series of deltas lying at two niveaux with a height difference of $28 \mathrm{~m}$ (Sau-

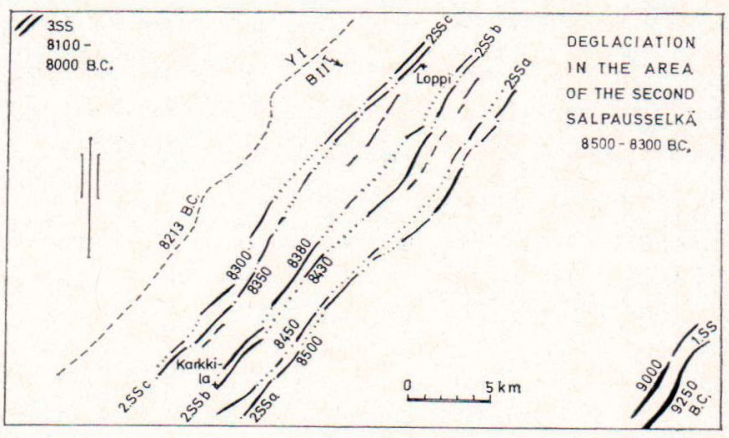

Fig. 6. Deglaciation within the 2nd Salpausselkä in $8500-8300$ B.C. The broken line, B II- $Y$ I, shows where the tilt of $c .28 \mathrm{~m}$ of the Baltic Ice Lake to the level of Yoldia I occurred in the terrain in 8213 B.C.

ramo 1958, Aartolahti 1968 and Niemelä 1971). According to Hyyppä $(1963,1966)$ and Nilsson (1968) the tilt of the Baltic Ice Lake to the level of Y I happened in 8213 B.C.

Northeast of the 2nd Salpausselkä system there were deposited some well-developed glaciofluvial deltas (e.g. Hauklammennummi), which also grew up to the water level of the ancient Baltic (The Baltic Ice Lake or Yoldia I). NW of Loppi the tilt of the Baltic Ice Lake is marked as two deltas lying at $152 \mathrm{~m}$ and $124 \mathrm{~m}$ above sea level (Fig. 2) (Aartolahti 1968 pp. $71-72)$.

\section{Other ice marginal formations}

In several areas belonging to the broken 2 nd Salpausselkä belts there are no distinct moraine ridges or deltas, but low sandy hills, or the material was deposited on the slopes of rocks or at the bottom of valleys. In the empty breaks of the belts, in the terrain there was deposited only a low hill or a small hill-side formation, composed of less-washed drift, without a distinct shape. In many such deposits there is no section that would show their structure and genesis.

It was found that the belts of the 2nd Salpausselkä in the study area were not as broken as presented on the maps published earlier. Fig. 2 
shows all the small deposits, identified by the author in the three belts of the 2nd Salpausselkä. Many of these formations are not marked on the geological maps by Virkkala (1963 pp. 37-38), the map of Quaternary deposits compiled by Virkkala (1967) or the geomorphological map of Aartolahti (1968).

\section{Deglaciation}

The general deglaciation within the system of the Salpausselkä formations in southern Finland has been studied earlier, e.g. by Sauramo (1923), V. Okko (1957), Virkkala (1963), Aartolahti (1968, 1972), Niemelä (1971) and Marjatta Okko (1972). The retreat of the ice front in the area of Karkkila, however, has been presented by these authors in the main on quite a large scale.

The ice marginal formations of the study area, especially the moraine ridges, give rise to some conclusions concerning the ice retreat within the 2nd Salpausselkä system. Each of the three separate belts of the 2nd Salpausselkä (2.SSa, 2.SSb and 2.SSc) are regarded in this study as synchronous ice marginal systems throughout their length. According to Sauramo (1923) the formation of the 2nd Salpausselkä lasted about 180 years. The melting ice margin receded quite steadily through the $10 \mathrm{~km}$ wide system of the 2nd Salpausselkä, but halted three times for about 30 years (Virkkala 1963 p. 45; see also Aartolahti 1968). According to Niemelä (1971 pp. 69-70) the 2nd Salpausselkä was formed over c. 200 years between $8500-8300$ B.C.

The small moraine ridges lie at quite even intervals, indicating short standstills or sometimes short local advances, perhaps for $1-3$ years. The deposition of the large ridges and deltas lasted longer, c. $10-30$ years. Fig. 6 schematically shows the author's opinion of the stages of retreat of the ice margin within the $2 \mathrm{nd}$ Salpausselkä in $8500-8300$ B.C. The present author has marked each of the three main halts (= formation of the belts) schematically as about 30 years and the separate retreats between these main belts as about $50-60$ years. Thus the formation of the whole 2nd Salpausselkä system lasted about 200 years.

The general position and formation of the 2nd Salpausselkä in the study area seem primarily to have been determined by climatic factors. In the main, it is topographical obstructions which have in general made the ice margin stagnate, and thus determined the locations of the ice marginal formations, as has also been pointed out by Virkkala (1963 pp. 46-47).

\section{REFERENCES}

Aartolahir, Torve (1968) Die Geomorphologie des Gebiets von Tammela, Südfinnland. Fennia 97 (7). 97 p.

- (1972) On deglaciation in southern and western Finland. Fennia 114. 84 p.

Embleton, Clifford, and Cuchlaine A. M. King (1969) Glacial and Periglacial Geomorphology, Edinburgh. 608 p.

GlüCKERT, GunNaR (1973) Glazialmorphogenese der weichseleiszeitlichen Moränen des Eckernförder Zungenbeckens (Schleswig-Holstein). Meyniana 23: $19-48$.
GrIPp, KARL (1964) Erdgeschichte von Schleswig-Holstein, Neumünster. 411 p.

HYYpPä, EsA (1963) On the late-Quanternary history of the Baltic Sea. Fennia 89 (1): $37-48$.

- (1966) The late-Quaternary land uplift in the Baltic sphere and the relation diagram of the raised and tilted shore levels. Ann. Acad. Sci. Fennicae, Ser. A, III, 90: 153-168.

LeIviskä, Irvari (1920) Der Salpausselkä. Fennia 41 (3). $388 \mathrm{p}$.

Mölder, KARL (1960) Toisen Salpausselän syntytavasta 
Jaalan kirkonkylän ja Saimaan välisellä alueella. Geologi 12 (1): $1-3$.

- (1966) Über die Entstehung des inneren Salpausselkä zwischen Jaala und Saimaa. Bull. Comm. Géol. Finlande 222: 75-92.

Niemelä, Jouko (1971) Die Quartäre Stratigraphie von Tonablagerungen und der Rückgang des Inlandeises zwischen Helsinki und Hämeenlinna in Südfinnland. Bull. Geol. Surv. Finland 253. 79 p.

Nilsson, ERIK (1968) Södra Sveriges senkvartära historia. Geokronologi, issjöar och landhöjningar. The LateQuaternary history of southern Sweden. Geochronology, ice-lakes and land-uplift. Kungl. Svenska Vetenskapsakademiens handlingar IV, 12 (1). 117 p.

Oкko, Marjatta (1972) Jäätikön häviämistapa Toisen Salpausselän vyöhykkeessä Lammilla. Summary: Deglaciation in the Second Salpausselkä ice-marginal belt at Lammi. Terra 84 (3): 115-123.

Oкко, Verkкo (1957) The Second Salpausselkä at Jylisjärvi, east of Hämeenlinna. Fennia 81 (4). 46 p.
Persson, Torsten (1974) Eskers, plateaux, terrace and other glaciofluvial forms in the southern and central parts of the South-Swedish Highlands. Geol. Fören. Förhandl. 96 (4): $411-419$.

Price, R. J., (1973) Glacial and fluvioglacial landforms. Edinburgh. 242 p.

Sauramo, Mattr (1923) Studies on the Quaternary varve sediments in southern Finland. Fennia 44. 164 p. - (1958) Die Geschichte der Ostsee. Ann. Acad. Sci. Fennicae, Ser. A, III, 51. 522 p.

TANNER, VÄINÖ (1938) Die Oberflächengestaltung Finnlands. Bidrag till kännedom av Finlands natur och och folk 86.762 p.

VirkKala, Kalevi (1963) On the ice-marginal features in southwestern Finland. Bull. Comm. Géol. Finlande $210.76 \mathrm{p}$.

- (1967) [Map of Quaternary deposits], 2042 Karkkila. Geological Map of Finland, 1: 100000.

Manuscript received, October 4, 1974. 